\title{
PENGARUH PENGGUNAAN MEDIA INSTAGRAM MODEL QUANTUM TEACHING TERHADAP KEMAMPUAN MENULIS PUISI SISWA KELAS X SMK HASYIM ASY'ARI PUCUK LAMONGAN
}

\author{
Mita Listiawati, Nisaul Barokati Selirowangi, Laila Tri Lestari
}

Fakultas Keguruan dan Ilmu Pendidikan, Universitas Islam Darul Ulum Lamongan email: mitalistiawati@gmail.com, nisa@unisda.ac.id, eilatrielestarie@gmail.com

\begin{abstract}
Abstrak
Penelitian ini bertujuan untuk mengetahui: (1) pengaruh media Instagram model Quantum Teaching ditinjau dari aktivitas siswa, (2) pengaruh media Instagram model Quantum Teaching ditinjau dari aktivitas guru, (3) pengaruh media Instagram model Quantum Teaching ditinjau dari ketuntasan belajar, dan (4) pengaruh media Instagram model Quantum Teaching ditinjau dari respon siswa kelas X SMK Hasyim Asy'ari Pucuk Lamongan. Jenis penelitian ini adalah penelitian kuantitatif melalui hasil uji coba eksperimen. Populasi penelitian ini adalah peserta didik kelas X MM SMK Hasyim Asy'ari Pucuk Lamongan sebagai kelompok pretes dan pascates. Data penelitian ini diperoleh melalui lembar observasi siswa, lembar observasi guru, tes soal esai, dan angket. Hasil penelitian menunjukkan bahwa presentase kemampuan menulis puisi siswa meningkat setelah mendapat perlakuan dengan menggunakan media Instagram model Quantum Teaching. Nilai rata-rata kelompok pretes yaitu sebesar 75,80 meningkat menjadi 85,80 dengan selisih sebesar $10 \%$.
\end{abstract}

Kata kunci: Instagram, Quantum Teaching, dan kemampuan menulis puisi.

\section{THE EFFECT OF INSTAGRAM QUANTUM TEACHING MODEL ON POETRY WRITING ABILITY OF CLASS X HASYIM ASY'ARI VOCATIONAL SCHOOL PUCUK LAMONGAN}

\begin{abstract}
This study aims to find out: (1) the influence of the Quantum Teaching model Instagram media in terms of student activity, (2) the influence of Quantum Teaching models of Instagram media in terms of teacher activities, (3) the influence of Quantum Teaching Instagram media media in terms of learning completeness, and (4) the influence of the Quantum Teaching model Instagram media in terms of the responses of class X students of SMK Hasyim Asy'ari Pucuk Lamongan. This type of research is quantitative research through the results of experimental trials. The population this study were students of class X MM SMK Hasyim Asy'ari Pucuk Lamongan as a pretest and post-test group. The data of this study were obtained through student observation sheets, teacher observation sheets, essay test questions, and questionnaires. The results showed that the percentage of students' poetry writing ability increased after receiving treatment using the Quantum Teaching media Instagram model. The average value of the pretest group of 75.80 increased to 85.80 with a difference of $10 \%$.
\end{abstract}

Keywords: Instagram, Quantum Teaching, and the ability to write poetry. 


\section{PENDAHULUAN}

Pendidikan pada dasarnya merupakan proses untuk membantu manusia dalam mengembangkan potensi dirinya sehingga mampu menghadapi setiap perubahan yang terjadi. Pendidikan dapat dikatakan berkualitas apabila proses belajar mengajar dapat berlangsung secara efektif dan peserta didik mengalami proses pembelajaran yang bermakna. Hal ini dapat dilihat pada hasil belajar yang dinyatakan dalam proses akademik dan kompetensi yang akan dicapai. Pendidikan dikatakan berkualitas apabila terjadi penyelenggaraan pembelajaran efektif dan efesien dengan melibatkan satu komponen yang dianggap penting melainkan komponenkomponen tersebut diberdayakan secara bersama-sama.

Media dalam prespektif pendidikan merupakan instrumen yang sangat strategis dalam ikut menentukan keberhasilan proses belajar mengajar. Keberadaannya secara langsung dapat memberikan dinamika tersendiri terhadap peserta didik. Media pembelajaran berbasis internet paling berpotensi untuk pengaruh yang dijadikan sebagai sumber belajar. Teknologi internet yang paling menjadi sorotan adalah perkembangan media sosial Facebook, Twitter, Path, Pinterest, Line, Tumblr, dan Instagram. Menurut Aditya, (2015:2) situs jejaring sosial Instagram merupakan salah satu situs yang paling potensial hal ini dikarenakan situs ini berfokus pada media gambar dan vidio. Melalui gambar dan vidio diharapkan siswa lebih tertarik dalam belajar bahasa Indonesia khususnya pada materi menulis puisi.

Penelitian yang telah dilakukan sebelumnya oleh Andri Usman Hadi (2018) menunjukkan bahwa model Quantum Teaching mampu menciptakan suasana baru dalam kelas. Hal tersebut dapat memicu semangat belajar siswa didukung dengan media visual terhadap kemampuan menulis siswa. Peserta didik memerlukan media pembelajaran yang bersifat baru agar proses pembelajaran tidak bersifat monoton. Sehingga model Quantum Teaching dengan media visual dapat berpengaruh dalam kemampuan menulis puisi.

Selain itu, terdapat penelitian yang telah dilakukan sebelumnya oleh Shinta Ayu Megawati (2018) menunjukkan bahwa media Instagram mampu memberikan pengaruh terhadap hasil belajar siswa pada mata pelajaran ekonomi. Semakin berkembangnya zaman, semakin berkembangnya pula teknologi. Seperti halnya media sosial Instagram, berbagai kalangan banyak yang menggeluti Instagram. Sehingga media Instagram sangat efektif digunakan dalam media pembelajaran.

Proses belajar mengajar di SMK Hasyim Asy'ari Pucuk Lamongan yang masih menerapkan pembelajaran yang menggunakan metode ceramah/ konseptual. Pembelajaran model ini ini guru cenderung hanya menyampaikan informasi kepada siswa. Hal ini dinilai kurang cocok digunakan pada perkembangan kurikulum saat ini. Pada pembelajaran tersebut siswa kurang aktif, banyak siswa yang beraktifitas diluar pembelajaran serta kurangnya motivasi siswa untuk belajar.

Pembelajaran model Quantum Teaching dengan menggunakan media Instagram diharapkan siswa dapat termotivasi dan memiliki semangat belajar yang tinggi. Jika siswa tersebut mempunyai motivasi belajar yang tinggi sehingga tidak terdapat kebosanan saat pembelajaran di dalam kelas. Media Instagram juga digemari para remaja saat ini, untuk berbagi foto maupun vidio. Adanya akun media Instagram 
@Omah_puisi siswa dapat memposting hasil karya menulis puisi. Sehingga ketidaktercapaian siswa terutama dalam menulis dapat diatasi dengan model pembelajaran Quantum Teaching dengan menggunakan media Instagram.

Berdasarkan permasalahan tersebut, penulis akan melakukan penelitian terhadap hal tersebut dengan judul "Pengaruh Media Instagram Model Quantum Teaching Terhadap Kemampuan Menulis Puisi Siswa Kelas $X$ SMK Hasyim Asy'ari Pucuk Lamongan".

\section{METODE PENELITIAN}

Penelitian ini adalah penelitian kuantitatif, penelitian ini diarahkan dalam bentuk mencari data-data kuantitatif melalui hasil uji coba eksperimen. Penentuan jenis penelitian kuantitatif ini dengan alasan semua gejala yang diamati dapat diukur dan diubah dalam bentuk angka serta dapat dianalisis dengan analisis statistik. Penelitian ini bertujuan untuk menguji teori, yaitu media pembelajaran dengan media sosial Instagram terhadap aktivitas siswa, aktivitas guru, ketuntasan belajar, dan respon peserta didik dalam menulis puisi.

Penelitian ini dilaksanakan di SMK Hasyim Asy'ari Pucuk Lamongan pada semester genap tahun pelajaran $2018 / 2019$. Subjek penelitian terdiri dari 25 siswa kelas X MM yang akan digunakan dalam kelompok pretes dan pascates. Instrumen-instrumen digunakan untuk mengukur variabel yang ada dalam penelitian. Instrumen yang digunakan untuk mengumpulkan data dalam penelitian ini adalah instrumen tes dan nontes berupa observasi, wawancara, dan angket.

Pengujian analisis data ini pertama yaitu melakukan uji normalitas data dengan menggunakan uji KolmogorovSmirnov. Data peneliti dikatakan menyebar dengan normal apabila nilai Kolmogorov-Smirnov atau nilai Asymp. Sig, (2-tailed) $>a=0,05$. Selanjutkan dilakukan uji homogenias, dengan harga $F$ yang diharapkan adalah harga $F$ yang tidak signifikan yaitu harga $\mathrm{F}$ empirik yang lebih kecil daripada harga $\mathrm{F}$ teoritik. Terakhir yaitu uji hipotesis ini menggunakan uji-t (independent uji test) yaitu menguji perbedaan rata-rata dari dua kelompok pretes dan pascates.

\section{HASIL DAN PEMBAHASAN}

Berdasarkan hasil analisis Independent Samples Test diperoleh nilai signifikasi pada Levene's Test for Equality of Variances untuk variabel aktivitas siswa adalah sebesar 0,440 yang dapat dikatakan bahwa data bersifat homogen, dan nilai signifikasi sevesar 0,000 (2-tailed). Rata-rata nilai lembar observasi siswa pada saat pembelajaran menggunakan media Instagram lebih tinggi daripada rata-rata nilai lembar observasi siswa pada saat pembelajaran model ceramah/ konvensional, yakni 87,76 dengan 96,84 .

Diperoleh nilai $T_{\text {hitung }}$ adalah 10,153 . Tabel distribusi t dicari pada a $=0,05$ (two tail test) diperoleh $T_{\text {tabel }}$ sebesar 2,01 dan Sig. $(0,000)<a(0,05)$. Nilai $T_{\text {hitung }}$ jatuh pada penerimaan $T_{\text {tabel }}$ yakni $T_{\text {hitung }}(10,153)>T_{\text {tabel }}$ $(2,01)$ atau $T_{\text {hitung }}(-10,153)<-T_{\text {tabel }}$ (-2,01) sehingga $T_{\text {hitung }}$ berada pada daerah penolakan $H_{O}$. Oleh karena itu dapat disimpulkan bahwa hipotesis yang diterima adalah aktivitas siswa dalam proses pembelajaran menggunakan media Instagram lebih tinggi daripada yang tidak diajar dengan media. 
Tabel 1 Perbandingan Hasil Pretes dan Pascates Aktivitas Guru

\begin{tabular}{|c|c|}
\hline Pretes & Pascates \\
\hline Pendahuluan : 10 skor & Pendahuluan : 19 skor \\
\hline Inti $\quad: 10$ skor & Inti $\quad: 18$ skor \\
\hline Penutup & Penutup \\
\hline Total skor: 80 & Skor: 98 \\
\hline
\end{tabular}

Berdasarkan perbandingan tabel 1 aktivitas guru diatas menjelaskan bahwa pada proses pembelajaran kelompok pretes atau sebelum adanya perlakuan mendapatkan nilai 80 untuk mencapai nilai 100 masih kurang 20. Sedangkan pada kelompok pascates atau pada saat pembelajaran menggunakna media mendapat nilai 98 untuk mencapai 100 hanya kurang 2. Selisih nilai kelompok pretes dan pascates dalam lembar observasi guru yaitu sebesar 18 .

Hasil analisis Independent Samples Test diperoleh nilai Sig. Levene's Test for Equality of Variances untuk variabel kemampuan menulis puisi adalah sebesar 0,092. Karena nilai sig. $0,092>0,05$, maka dapat disimpulkan bahwa varians data kemampuan menulis puisi adalah homogen. Perbandingan nilai menulis puisi menggunakan media dan tidak menggunakan media. Ratarata nilai siswa yang diajar menggunakan media Instagram lebih tinggi daripada rata-rata nilai siswa yang diajar tanpa menggunakan media, yakni 75,80 dengan 85,80.

Diperoleh nilai $T_{\text {hitung }}$ adalah $-3,749$. Tabel distribusi t dicari pada $a=0,05$ (two tail test) diperoleh $T_{\text {tabel }}$ sebesar 2,01 dan Sig. $(0,000)<$ a $(0,05)$. Nilai $T_{\text {hitung }}$ jatuh pada penerimaan $T_{\text {tabel }}$ yakni $T_{\text {hitung }}(3,749)>T_{\text {tabel }}(2,01)$ atau $T_{\text {hitung }}(-3,749)<-T_{\text {tabel }}(-2,01)$ sehingga $T_{\text {hitung }}$ berada pada daerah penolakan $H_{O}$. Oleh karena itu, dapat disimpulkan bahwa hipotesis yang diterima adalah kemampuan menulis puisi yang diajar dengan menggunakan media
Instagram lebih tinggi daripada yang tidak diajar dengan media.

Hasil analisis Independent Samples Test diperoleh nilai Sig. Levene's Test for Equality of Variances untuk variabel aktivitas siswa adalah sebesar 0,166 . Nilai sig. $0,166>0,05$, maka dapat disimpulkan bahwa varians data respon siswa adalah homogen. Rata-rata nilai respon siswa yang diajar menggunakan media Instagram lebih tinggi daripada rata-rata nilai respon siswa yang diajar tanpa menggunakan media, yakni 61,36 dengan 71,16.

Diperoleh nilai $T_{\text {hitung }}$ adalah -4,102. Tabel distribusi t dicari pada $a=0,05$ (two tail test) diperoleh $T_{\text {tabel }}$ sebesar 2,01 dan Sig. $(0,000)<a(0,05)$. Nilai $T_{\text {hitung }}$ jatuh pada penerimaan $T_{\text {tabel }}$ yakni $T_{\text {hitung }}(4,102)>T_{\text {tabel }}(2,01)$ atau $T_{\text {hitung }}(-4,102)<-T_{\text {tabel }}(-2,01)$ sehingga $T_{\text {hitung }}$ berada pada daerah penolakan $H_{O}$. Oleh karena itu dapat disimpulkan bahwa hipotesis yang diterima adalah respon siswa dalam pembelajaran menggunakan media Instagram lebih tinggi daripada yang tidak diajar dengan media.

\section{SIMPULAN DAN SARAN \\ Simpulan}

Berdasarkan dasil penelitian dan pembahasan yang telah dikemukakan pada bab sebelumnya, dapat disimpulkan beberapa hal sebagai berikut: (1) Penggunaan media Instagram model Quantum Teaching pada pembelajaran menulis puisi siswa kelas X MM SMK Hasyim Asy'ari Pucuk Lamongan memberikan pengaruh positif terhadap aktivitas siswa. Nilai rata-rata kelompok pretes yaitu sebesar 87,76 meningkat menjadi 96,84. (2) Penggunaan media Instagram model Quantum Teaching pada pembelajaran menulis puisi siswa kelas X MM SMK Hasyim Asy'ari Pucuk Lamongan memberikan pengaruh 
positif ditinjau dari aktivitas guru. Skor yang dicapai guru pada kelompok pretes sebelum diberikan perlakuan yaitu 80 sedangkan skor yang dicapai guru pada kelompok pascates setelah diberikan perlakuan adalah 98. Dibuktikan dengan naiknya nilai/skor yang didapatkan guru dalam proses mengajar menulis puisi yakni sebesar 18\%. (3) Penggunaan media Instagram model Quantum Teaching pada pembelajaran menulis puisi siswa kelas X MM SMK Hasyim Asy'ari Pucuk Lamongan memberikan pengaruh positif terhadap ketuntasan belajar siswa. Nilai rata-rata kelompok pretes yaitu sebesar 75,80 meningkat menjadi 85,80. (4) Penggunaan media Instagram model Quantum Teaching pada pembelajaran menulis puisi siswa kelas X MM SMK Hasyim Asy'ari Pucuk Lamongan memberikan pengaruh positif terhadap respon siswa. Nilai rata-rata kelompok pretes yaitu sebesar 61,36 meningkat menjadi 71,16.

\section{Saran}

Berdasarkan hasil penelitian dan pembahasan yang telah dikemukakan pada bab sebelumnya, peneliti menyarankan: (1) Bagi guru, media pembelajaran Instagram model Quantum Teaching dapat dijadikan sebagai salah satu media dalam pembelajaran menulis puisi karena mampu membuat siswa lebih mudah menemukan ide-ide pokok dalam menulis puisi, (2) Bagi siswa, media Instagram dapat dijadikan sarana untuk berlatih menulis puisi dan memposting hasil karya menulis sehingga dapat meningkatkan minat dan prestasi belajar siswa, dan (3) Bagi peneliti lain, media Instagram model Quantum Teaching dalam menulis puisi dapat dijadikan sebagai salah satu referensi untuk penelitian selanjutnya.

\section{DAFTAR PUSTAKA}

Adi, Triyo. "Pengaruh Media Lagu Terhadap Kemampuan Menulis Puisi Pada Siswa Kelas X SMA Negeri I Pejagoan Tahun Pelajaran 2016/2017". SKRIPSI. 2017, hal1419.

repository.umpwr.ac.id:8080/bitstrea $\mathrm{m} /$ handle/.../132110170-

Triyo\%20Adi.pdf. Diakses tanggal 25 Oktober

Aditya, Rangga. "Pengaruh Media Sosial Instagram Terhadap Minat Fotografi pada Komunitas Fotografi Pekanbaru". Jurnal Jom FISIP. Oktober 2015, 2, hal 3. https://jom.unri.ac.id/index.php/JOM FSIP/article/view/5880. Diakses tanggal 8 Juli

Citraningrum, Dina Merdeka. "Menulis Puisi dengan Teknik Pembelajaran yang Kreatif"'. Februari 2016, 1, hal 83.

http://jurnal.unmuhjember.ac.id/inde x.php/BB/article/view/75. Diakses tanggal 7 Januari

Hadi, Andri Usman. 2018. Pengaruh Model Quantum Teaching Didukung Media Visual Terhadap Kemampuan Menulis Puisi Siswa Kelas X SMA Muhammadiyah Kediri Tahun Pelajaran 2017/2018. Skripsi Sarjana. Kediri: Fakultas Keguruan dan Ilmu Pendidikan Universitas Nurantara PGRI Kediri. http://simki.unpkediri.ac.id/ Diakses tanggal 5 Februari

Karo, Suriya Emanita Br. "Efektivitas Penggunaan Media Bagan dalam Meningkatkan Kemampuan Berpidato oleh Siswa Kelas IX SMP Negeri I Pancur Batu Tahun Pembelajaran 2013/2014. PDF 
Creator-PDF4Free

v3.0.

http://www.pdf4free.com. Hal 2.

https://media.neliti.com/media/public ations/56708-ID-efektivitas-

penggunaan-media-bagan-dalam.pdf.

Diakses tanggal 17 Februari

Megawati, Shinta Ayu. 2018. Pengaruh Instagram Terhadap Hasil Belajar Siswa pada Mata Pelajaran Ekonomi di SMA Pasundan 2 Bandung. Skripsi Sarjana. Bandung: Fakultas Keguruan dan Ilmu Pendidikan Universitas Pasundan Bandung. http://repository.unpas.ac.id/37782/.

Diakses tanggal 19 Juni

Shoimin, Aris. 2014. 68 Model Pembelajaran Inovatif dalam Kurikulum 2013. Rembang: Ar-ruzz Media.

Siregar, Irdes Hidayana., dkk. "Pengaruh Model Pembelajaran Quantum Teaching Terhadap Hasil Belajar Siswa Pada Materi Pokok Zat dan Wujudnya di Kelas VII Semester I SMP Negeri 3 Percut Sei Tuan T.P 2013/2014". Jurnal Inpafi. Mei 2014, 2, hal. 94. https://anzdoc.com/irdes-hidayanasiregar-dan-rita-juliani-jurusanfisika-fmipa.html. Diakses tanggal 25 Desember
Sodikin, Mohamad., dkk. "Pengaruh Quantum Teaching Terhadap Hasil Belajar Siswa pada Pokok Bahasan Hukum Newton di Kelas X SMA Wahid Hasyim 4 Sidoarjo”. Jurnal Inovasi Pendidikan Fisika (JIPF). 2014, 2, hal 11. https://journal.ipm2kpe.or.id/index.p hp/SPEJ/article/view/465/314.

Diakses tanggal 14 Maret

Sri, Ratna, dkk. "Pengaruh Penerapan Model Pembelajaran Quantum Teaching Terhadap Pemahaman Konsep Matematis Berdarakan Minat Belajar Matematika Siswa Sekolah Menengah Pertama Kampar”. Jurnal for Research in Mathematic Learning. September 2018, 2, hal 130. repository.uinsuska.ac.id/12844/. Diakses tanggal 12 Februari

Utami, Rina Putri., dkk. "Pengaruh Model Pembelajaran Project Based Learning Berbantu Instagram Terhadap Kemampuan Berpikir Kreatif Siswa Kelas X SMA Negeri 8 Surakarta”. Jurnal Bio-Pedagogi. April 2015, hal 47. https://docplayer.info/48535066Pengaruh-model-pembelajaranproject-based-learning.html. Diakses tanggal 4 Oktober 